\title{
Spiritual Development Across The Curriculum In Educational Systems
}

\author{
Ghasempoor Ali \\ Department of Education \\ Payame Noor University, Tehran, Iran
}

\begin{abstract}
This paper looking back over the last several years and asserts that the spiritual is rooted in the essence of being human and shows how spirituality is related to a search for a deeper philosophical meaning of life. Human beings search for meaning, purpose and direction in life and spiritual development is inextricably linked with this process Spiritual development in this sense must be holistic. The spiritual dimension of education must engage the body, mind and heart. Spiritual development implies change, with a progression from immaturity towards maturity, from the simple to the complex, from the superficial to the profound. In relation to this the writer discusses what spiritual education should involve and the contribution different aspects of the curriculum can make.
\end{abstract}

Keywords: spiritual development, spirituality, curriculum, curriculum orientation, education.

\section{INTRODUCTION}

During the past decades in education, specifically curriculum has also followed what has been happening in society. The subject matter curriculum with its characteristics of fragmentation, memorization, textbook orientation, teacher as controller, cognitive-based, and norm-testing is now being questioned. It is especially being questioned by those who feel that the modem, industrial efficiency paradigm is no longer relevant for today's curriculum. We seemed to be looking for something more in the curriculum.

William Doll (1993) states this: "This concept of standardized norms lying within a stable-state universal lies at the very heart of the modernist paradigm. It also is a concept the post modernist paradigm, on all its variations, challenges and rejects" (p. 54). We believe the subject matter curriculum is still caught up in the scientific management movement of the 1920s. ...

\section{The role of spirituality in education}

de Souza's research for the past twenty years has examined the role of spirituality in education in terms of nurturing the relational aspects of students' lives, thereby promoting experiences of connectedness (see de Souza, 2003, 2004, 2006, 2009, 2013, 2014, 2016). de Souza have identified how the spiritual dimension of learning contributes to mental, emotional and physical wellbeing and, potentially, to the nurturing of socially cohesive communities. The author has also argued that the spiritual dimension of western education was seriously neglected in the previous century for a variety of reasons (de Souza, 2006, 2016). For instance, there was a concentration on cognitive learning to provide students with knowledge and skills for the workforce in the twentieth century. As well, there was a commonly held perception in the western world that spirituality pertained to religious life and, therefore, was the 
prerogative of those belonging to a faith tradition. Such thinking firmly placed spirituality in the personal realm of individual and communal life.

In all countries, spiritual and moral development is being used increasingly with reference to general education and all educational systems. Spirituality is a difficult concept to define. While it has been explored throughout human history as one of the three fundamental aspects of human beings (i.e., body, mind, spirit) (Huitt, 2003), there is widespread disagreement as to its origin, functioning, or even importance (Huitt, 2000). However, in a broad perspective, spirituality deals fundamentally with how we approach the unknowns of life, how we define and relate to the sacred.

When people apply concepts of spirituality to education, academics often see a problem in the term's lack of a common definition. Some feel that spirituality is too subjective to be of value in the objective, empirical world of academia. Others are afraid that it is associated with an attempt to influence curriculum to match religious views. But if connectedness is a primary aspect of spirituality, then what spirituality threatens most is the inherent fragmentation in our educational structures. Parker Palmer, in his most recent book, The Courage to Teach, advises that "if we want to develop and deepen the capacity for connectedness at the heart of good teaching, we must understand - and resist - the perverse but powerful draw of the 'disconnected' life" (p.35). How, and why, does academic culture discourage us from living connected lives? How, and why, does it encourage us to distance ourselves from our students and our subjects, to teach and learn at some remove from our own hearts?

For Palmer the answer seems obvious: "we are distanced by a grading system that separates teachers from students, by departments that fragment fields of knowledge, by competition that makes students and teachers alike wary of their peers and by a bureaucracy that puts faculty and administration at odds" (pp. 35-36).Recently, in Educational Leadership, Palmer expanded on the question of spirituality in education:

I reject the imposition of any form of religion in public education, including so-called "school prayer." But I advocate any way we can find to explore the spiritual dimension of teaching, learning, and living. By "spiritual" I do not mean the creedal formulations of any faith tradition, as much as I respect those traditions and as helpful as their insights can be. I mean the ancient and abiding human quest for connectedness with something larger and more trustworthy than our egos - with our own souls, with one another, with the worlds of history and nature, with the invisible winds of the spirit, with the mystery of being alive. (p. 6)

Spirituality in education, then, has to do with going beyond the acquisition of knowledge and entering the realms of meaning and purpose. Do these elements have a place in college and university classrooms? One recent experiment explored this question. In the spring of 1998, Victor Kazanjian, dean of religious and spiritual life at Wellesley College, gathered students together and asked them to share stories about instances in which they had experienced moments of inspiration, connection, wonder, and awe in their classes. One by one, they recounted tales of such experiences in classes that ranged over the full spectrum of the curriculum.

Dean Kazanjian then approached the faculty members in whose classrooms these experiences had taken place, inviting them to a discussion about such moments in the learning and teaching process. Nearly all of those faculty members subsequently attended a series of discussions and shared similar stories with one another about moments of meaning in their own learning and 
teaching. As Kazanjian puts it, "Some faculty members - who responded in the past with blank stares and occasionally overt expressions of anger at the presumption of speaking about spirituality and scholarship in the same breath -- seemed now to see the connection" (p. 39).

The past few decades have seen considerable research on spiritual development in schools. What follows is a selection of perhaps the most influential in terms of impact on schools .The work of researchers like Rebecca Nye and David Hay helped establish the significance of spiritual development in educational policy but the academic debate didn't always translate into classroom practice, although it remains hugely significant in RE.

For many in schools spiritual development was a term that was limited to what the RE department did a lot of, (especially in that difficult Attainment target 2 bit), and what collective worship at its best did. There was a recognition that occasionally there were examples of 'Awe and Wonder' across the curriculum but these were ad hoc and notable for taking staff by surprise. Approaches such as Michael Beesley's 'Stilling' became popular and helped establish a practical link in teacher's minds between spiritual development and improving teaching and learning (particularly pupil behavior).

David Smith's work for the Stapleford Centre 'Making sense of Spiritual Development' 1999 helpfully presented a structure for mapping and progression of spiritual development across the curriculum. He suggested four windows into spiritual development:

- Spiritual Capacities: recognition that all human beings are capable of spiritual growth through capacities such as self-awareness, reflection, empathy, imagination and creativity.

- Spiritual Experiences: ways in which pupils can encounter the spiritual dimension of life

- Spiritual Understanding: the need to have developed an understanding to make sense of the spiritual experiences encountered and capacities exercised

- Spiritual responses: how this experience and understanding impacts on our lives and shapes the way in which we live our lives.

\section{Curriculum subjects and spiritual development}

All curriculum subjects can contribute to students 'spiritual development (Newby, 1988 and 1997; Patten,1992) because all subjects can provoke curiosity, reflection (Hill, 1989), enjoyment and the wonder of the human spirit (Marratt, 1985) or what White p. 373) calls 'contemplation of the existence of life'.

Word limits prevent a comprehensive coverage of the contributions of all curriculum subjects to spiritual development. Therefore, by way of illustration, the following sections will suggest ways in which 'the arts', RE, mathematics and science can contribute to spiritual development.

\section{The arts and spiritual development}

The word spiritual is often used in conjunction with aesthetic experience. The arts can be a means to develop spiritual characteristics, such as creativity, the imagination, empathy, a search for meaning and purpose, truth and so on. The arts provide a stepping stone to structure meaning in relation to experience (Watson, 1993). The arts allow a unique entry to the exploration of experience at depth and an encounter with mystery, which according to Slee (1992, p. 51) are the keys to developing spiritual sensitivity and awareness. The arts are where students can encounter personal and ultimate feelings and beliefs, which affirm or give meaning to one's humanity (Yeomans, 1993, p. 71). The understanding of figurative and 
symbolic meanings, the transcendent and refinement of thoughts and feelings are all inextricably linked with the arts (Attridge, 1993, p. 46). Moreover, the natural language of the spiritual is that of symbol and paradox (Watson, 1993, p. 82), metaphor and analogy (Carr, 1995, p. 95) that may be found in music, poetry, prose and so on. As Harries (1993, p. 101) contends, all works of art, whatever their content, have a spiritual dimension.

Slee (1992) points out that paying attention to the particular opens access to a profound awareness of the universal. An examination of Blake's flowers or Van Gogh's peasant shoes can stimulate curiosity and insight. Employing icons, calligraphy, sculpture, stained glass, mosaics and paintings in classrooms, allows exploration of human experiences and responses to fundamental issues such as life and death (Chapman, 1999). Studying Wilde's The Selfish Giant, Shelley's Frankenstein and Shakespeare's plays, can promote a pondering of human ideals, ambitions and aspirations (Disney and Pound, 1999). Similarly, drama and music help students to enter imaginatively into a wide range of human predicaments (see Bigger and Thomas, 1999), shedding light on the human condition (Stead, 1999).

\section{RE and spiritual development}

Some writers (for example, Rodger, 1982; and Slee, 1992) believe that RE is fundamentally related to spiritual development. RE promotes spiritual development by enhancing students' awareness of, and sensitivity towards core human values (Grimmitt, 1987, p. 168). RE, according to Holley (1978), is essentially concerned with the provocation of spiritual insight, particularly where RE assists students in theirs search for meaning in the midst of experience (Ollington cited in Slee, 1992). Slee (1992, p. 42) maintains that RE is essentially process rather than content. It is a process which is characteristically inquisitive and explorative, rather than instructive and explanatory; experimental and inductive rather than didactic and deductive; open-ended and risky rather than predetermined and safe; personal and relational rather than academic and detached; holistic and integrative rather than abstract and analytical. It is a process that fosters spiritual growth and identity rather than religious beliefs of any particular tradition. Such a process can lead to reflections on oneself, one's beliefs and one's values (Grimmitt, 1987, p. 164). RE provides a setting for which the nature and source of the spiritual is most explicitly addressed. In other words, it is concerned with the meaning of existence and the nature of humanity (Brown and Kadodwala, 1993, p. 35); this involves a search for meaning and truth and an encounter with mystery and transcendence (Hay, 1985), empathy and understanding (Smart,1975), all characteristics of the spiritual.

Providing moments of quiet reflection on, for example, Rembrandt's The Prodigal Son, or appropriate readings from sacred texts, such as Psalm 8 or Ecclesiastes (see Happiseva, 1989), can provide insight into the human condition, exploring feelings of failure, isolation, reconciliation, joy, celebration, resurrection in daily life and so on. Experience suggests that many RE teachers are skilled in using appropriate resources and settings to stimulate spiritual sensitivities.

\section{Mathematics and spiritual development}

According to French (1990, p. 170), to speak of awe, wonder or delight in relation to mathematics will seem strangely inappropriate to many people, including to some of those who teach the subject. HMI, reporting in 1979 (cited in French, 1990 p. 170), commented that some approaches to mathematics failed to provoke a sense of enquiry, stimulus to curiosity or appeal to the imagination. Foshay (1990) suggests that great teachers are those who find what is captivating or transcendent about their disciplines, and use this insight to awaken in their students transcendent experiences. 
Foshay shows how mathematics is capable of engaging students with the spiritual. Mathematics, argues Foshay, goes beyond what is immediately received. Moreover, mathematics deals with some 'ultimate questions' about proof, the finite and infinite, symbolism, the ideas of nothing and something (existence and reality) when working with zero and negative numbers. In other words, mathematics is capable of astonishing students, hence it is potentially, and for some, actually majestic and powerful. There are opportunities to inspire awe and wonder (Lankshear, 1992, pp. 32-3), as well as freedom of thought and the imagination (Foshay, 1990; Jones, 1999).

Mathematics is also rooted in the human because only human beings engage in mathematics (Foshay, 1990, p. 107). Furthermore, those students who experience success in mathematics, as in all curriculum subjects, can receive a boost to their self-confidence and therefore their self-esteem. In all of these ways, mathematics can make a contribution to students' spiritual development.

\section{Science and spiritual development}

Science can be a significant contributor to spiritual development. Using microscopes in the classroom can raise questions about what lies beyond the boundaries of sight and the limitations of human intelligence (Webster, 1991, p. 57). Indeed, the driving force of science is the sense of wonder at the marvelous pattern of the physical world revealed by one's inquiry (Polkinghorne, 1992, p. 252). Such a search for understanding and the experience of wonder is a spiritual experience, albeit grounded in scientific language. Science can be a vehicle for entering into the mysteriousness of materiality more deeply and as such is relevant to the quest to lead spiritual lives (Honner, 1985, pp. 202-5). Moreover, older students can appreciate creative thought in interpreting scientific evidence, whilst astronomy, for example, offers scope for reflection on the place of humanity in a universe so vast, so organized and so beautiful (QCA, 1997). Given that science aims to gain as full and accurate a picture as possible, transcendental experience or 'the spiritual aspect of life' is pertinent to science (Josephson, 1987, p. 15). The potential for astonishment, wonder and awe, reflection and stimulating the inclination to question, links science education to spiritual development (McFadden, 1999).

\section{DISCUSSION}

Curriculum orientations will influence students because the underlying values and beliefs of each orientation not only influence what is taught, but also why and how it is taught (Eisner, 2002). This paper has asserted that the spiritual is rooted in the essence of being human. Human beings search for meaning, purpose and direction in life and spiritual development is inextricably linked with this process. Moreover, the spiritual recognizes that there is a depth to living beyond the physical body and material world. Paradoxically, the spiritual is also concerned with matters at the heart and root of existence.

The co-ordinates of the spiritual are thought, freedom, transcendence and the quest for ultimate values: truth, wholeness, justice and peace. Spiritual development is a process that engages with the search for meaning in experience, values, and issues of self-identity and sensitivity to others; it recognizes the uniqueness of persons and implicit in this process is the move from immaturity to maturity. Self-understanding and self-acceptance are crucial aspects of spiritual development and are pertinent for all.

A curriculum that aims to promote spiritual development must be holistic and integrative. A curriculum is holistic where feelings, emotions, values, beliefs, behavior, aspirations and the intellect are catered for. A curriculum that allows for spiritual development is broad rather than narrow. An integrative curriculum engages the mind, body and spirit in a way where 
learning experiences are integrated in the sense that there is an attempt to unify the whole range of experiences that students encounter. Learning in one area of the curriculum is recognized as having relevance to other curriculum areas. In the spirit of the 1944 Education Act, the spiritual is intended to pervade the whole educational process.

Stimulating a sense of the spiritual requires that students have opportunities for using their imaginations; for creativity, exploration, wonder, awe, a sense of mystery and an environment not only where students are at ease asking questions, but questioning received views. This enables students to search for meaning in experience and truth. These are essential elements in a curriculum that promotes spiritual development. A curriculum that aims to promote spiritual development must also provide opportunities for silence, inner listening, a sense of wonder and sensitivity to the emotions. These opportunities may lead to transcendence and empathy with those in need. Promoting self-worth is also important and this ought to be reflected in the relationships, structures, systems and rules of the institution. In other words, the formal and informal curriculum aims to develop in student's self-knowledge, self-esteem and encourages students to make sense of their experiences.

\section{References}

Arbuckle, G. A. (1990) Earthling the Gospel. London: Geoffrey Chapman.

Coles, R. (1990) The Spiritual Life of Children. London: Harper Collins.

Lealan, B. (1993) 'Drum, Whalebone and Dominant X: A Model for Creativity', in D. Starkings (ed.), Religion and the Arts in Education, pp. 55-66. London: Hodder \& Stoughton.

de Souza, M. (2016) The Spiritual Dimension of Education ñ Addressing Issues of Identity and Belonging, Discourse and Communication for Sustainable Education, vol. 7, no. 1, pp. 125-138

de Souza, M. (2014). The empathetic mind: The essence of human spirituality. International Journal of children's Spirituality 19(1), pp. $45-54$.

de Souza, M (2012a). The dual roles of unconscious learning in engendering and hindering spiritual growth: Implications for religious education in pluralist contexts. In Jeff Astley \& Leslie Francis (Eds). Teaching religion, teaching truth, (pp. 184-203). Bern, Switzerland: Peter Lang AG International Academic Publishers.

de Souza, M. (2012b). Connectedness and connectedness. The dark side of spirituality: Implications for education. International Journal of children's Spirituality 17(3), 291-304. [Web of Science]

de Souza, M. (2009). The spiritual dimension in educational programs and environments to promote holistic learning and wellbeing: An introduction. In M. de Souza, L. Francis, J. O’Higgins-Norman, \& D. Scott,

(Eds). International handbook of education for spirituality, care and wellbeing (pp. 525-532). Dordrecht, The Netherlands: Springer Academic Publishers.

Eisner, E. (2002). The educational imagination: On the design and evaluation of school programs (3rd ed.). New Jersey and Ohio: Merrill Prentice Hall.

Freire, P. (1972) Pedagogy of the Oppressed. Harmondsworth, Middlesex: Penguin Books.

French, D. (1990) 'Mathematics: An Appeal to the Imagination, Curriculum, 11 (3), pp. 170-5.

Hardy, A. (1979) The Spiritual Nature of Man. Oxford: Oxford University Press.

Hay, D. (1982) Exploring Inner Space. London: Penguin Books.

Hay, D. (1985) 'Suspicion of the Spiritual: Teaching Religion in a World of Secular Experience', British Journal of Religious Education, 7 (3), pp. 140-7.

Hess, C. L. (1991) 'Educating in the Spirit', Religious Education, 86 (3), pp. 383-98.

Huitt, W. (2000). The spiritual nature of a human being. Educational Psychology Interactive. Valdosta, GA: Valdosta State University. Retrieved May 22, 2001, from

Huitt, W. (2003). A systems model of human behavior. Educational Psychology Interactive. Valdosta, GA: Valdosta State University. Retrieved: June 2003 
King, U. (1984) 'Religious Education: Transcendence and Liberation. Unpublished paper of the address at the CEM Conference, Kings College, London, 13 June 1984.

Ofsted (1993) Handbook for the Inspection of Schools. London: HMSO.

Ofsted (1994) Spiritual, Moral, Social and Cultural Development. London: HMSO.

Palmer, P.J. (1998)The Courage to Teach: Exploring the Inner Landscape of a Teacher's Life. San Francisco: JosseyBass,

Palmer, P. J.(1998) "Evoking the Spirit." Educational Leadership, Dec. 1998-Jan. 1999, pp. 6-11.Walsh, D. C. Opening remarks to the Education as Transformation National Gathering, Wellesley College,

Priestley, J. G. (1992) 'Whitehead Revisited - Religion and Education: An Organic Whole', in B. Watson (ed.), Priorities in Religious Education, pp. 26-37. London: The Falmer Press.

Plunkett, D. (1985) 'The Timeless and the Timely', in P. C. Souper (ed.), The Spiritual Dimension of Education, pp. 1-5. Southampton: Department of Education, University of Southampton.

Qca (1997) The Promotion of Pupils' Spiritual, Moral, Social and Cultural Development. Draft Guidance for Pilot Work, London: QCA Publications.

Rodger, A. R. (1996) 'Human Spirituality: Towards an Educational Rationale', in R. Best (ed.), Education, Spirituality and the Whole Child, pp. 45-63. London: Cassell.

Slee, N. (1992) 'Heaven in Ordinarie: The Imagination, Spirituality and the Arts in Religious Education', in B. Watson (ed.), Priorities in Religious Education, pp. 38-57. London: Falmer Press.

Stead, P. (1999) 'Music', in S. Bigger and E. Brown (eds), Spiritual, Moral, Social and Cultural Education, pp. $130-8$. London, David Fulton Publishers.

WEBSTER, D. H. (1982) 'Spiritual Growth in Religious Education, Aspects of Education, 28, pp. 85-95.

Webster, D. H. (1985a) 'The Spiritual Development of Children, Clergy Review, LXIX (1), pp. 28-33. 